\title{
A NEGATIVIDADE DA LINGUAGEM E A VOZ EM GIORGIO AGAMBEN
}

Sarah Valle Camargo

RESUMO

$\mathrm{O}$ artigo revê a relação entre linguagem e morte, a partir do livro A Linguagem e a Morte, no qual G. Agamben trata da negatividade fundamental do ser da linguagem e do ser do homem como motores dialéticos que permitem a abertura do ser no ter-lugar da linguagem, sustentado pela negatividade da Voz. Suscitamos, desta reflexão, questionamentos acerca do status da linguagem na contemporaneidade.

PALAVRAS-CHAVE: negatividade da linguagem; linguagem e morte; Giorgio Agamben.

\section{Introdução}
negatividade da linguagem (o $N a \tilde{o} o^{1}$ que a compóe, sua incapacidade de apreender-o-Isto ${ }^{2}$ ) a mantém num sempre remeter-se a si mesma. Esta negatividade constitui seu modo de transcendência, seu "ser" (afirmado pela capacidade de se autorreferir). Por transcender, a linguagem permite ao homem abrir-se nela, em constante busca pela sua voz. Ambas as aberturas, a do ser do homem no ter-lugar da linguagem e a do ser da linguagem em si, através do homem, seriam sustentadas, a partir do que nos apresenta Agamben, em sua dupla negatividade, por uma Voz. Esta, shifter supremo, busca essencial da metafísica, a qual, uma vez perdida, como sobreviver à sua ausência?
1 Itálicos de Giorgio Agamben.
2 Tradução do termo das Diese nehmen, de Hegel em Fenomenologia do Espírito. AGAMBEN, Giorgio. A Linguagem e a Morte: um seminário sobre o lugar da negatividade. Belo Hori- zonte: Ed. UFMG, 2006. p. 18.




\section{DO SER MORTAL E FALANTE: DASEIN E DIESE NEHMEN}

Em A Linguagem e a Morte, Giorgio Agamben ${ }^{3}$ articula as noçóes de Dasein (Heidegger) e de Diese nehmen (Hegel), tratando da negatividade fundamental do ser da linguagem e do ser do homem como motores dialéticos que permitem a própria abertura do ser no ter-lugar da linguagem.

O homem é falante e mortal. Ser negativo, que "é o que não é, e não é o que é", nas palavras de Hegel, e "o lugar-tenente (Platzhalter) do nada", nas de Heidegger ${ }^{4}$. É, para Heidegger, Dasein, ser-lançado, pró-jeto projetado, que não é conduzido por si ao seu $D a$, não tendo posto seu próprio fundamento. É poder-ser, que pertence a si mesmo, embora náo como se tivesse dado a si a própria posse $e^{5}$. Repousa em seu peso, sendo fundamento, existindo como lançado constantemente atrás de suas possibilidades. Este Não que o constitui pertence ao sentido existencial do ser-lançado. Sendo fundamento de uma negatividade, ele próprio é uma negatividade em si mesmo (negatividade de fundo). A experiência da morte (Dasein é ser-para-a-morte) o faz encontrar sua possibilidade mais própria. Iluminado em si enquanto ser-no-mundo, não através de outro ente, ele é a clareira luminante. A possibilidade de ser o $D a$ é assumida através da experiência de ser-para-a-morte. Dasein, portanto, é ser-o- $D a($ ser-o- $a \hat{\imath})$, estar em casa no próprio lugar ${ }^{6}$. Da que se revela como o lugar a partir do qual ameaça uma negatividade radical (instância de finitude), posto que algo na pequena palavra $D a$ nulifica, introduz a negação naquele ente - o homem - que deve ser seu $A i$.

O ente, que se constitui essencialmente através do ser-no-mundo, é ele mesmo sempre o seu $D a$. Em seu significado habitual, $D a$ quer dizer "aqui" ou "lâ". "Aqui" ou "lâ" só são possíveis em um $D a$, ou seja, somente se existe um ente que, como ser do $D a$, abriu a sua espacialidade. O principal caráter do

3 AGAMBEN, Giorgio. A Linguagem e a Morte: um seminário sobre o lugar da negatividade. Belo Horizonte: Ed. UFMG, 2006.

4 AGAMBEN, Giorgio. A Linguagem e a Morte: um seminário sobre o lugar da negatividade. Belo Horizonte: Ed. UFMG, 2006. p. 10-11.

5 HEIDEGGER, Martin. Sein und Zeit [Ser e tempo]. 1. ed. Halle:Tübingen, 1927. p. 283285 apud AGAMBEN, Giorgio. A Linguagem e a Morte: um seminário sobre o lugar da negatividade. Belo Horizonte: Ed. UFMG, 2006. p. 14-15.

6 AGAMBEN, Giorgio. A Linguagem e a Morte: um seminário sobre o lugar da negatividade. Belo Horizonte: Ed. UFMG, 2006. p. 17. 
Dasein é o não-fechamento. A expressão $D a$ significa esta essencial abertura. $\mathrm{O}$ Dasein comporta o seu $D a$ (essencial abertura) desde o início (von Hause aus).

Ser-o-Da é ser um aqui ou um lá, portanto, o ser encontra-se na imagem da referência, imagem do advérbio, que aponta, "circunstancialmente", não significa. E sendo Etre-le-là, existerium (ser, sustentar-se no fora) no seu $D a$, esta abertura ocorre dentro da linguagem, para Heidegger, a casa do ser ${ }^{7}$.

O advérbio de lugar do $D a$ é símbolo-índice, duplamente categorizado segundo a tabela semiótica de Charles Peirce ${ }^{8}$, uma vez que se trata tanto de um signo convencionado socialmente quanto de um que, no momento em que existe, está ligado fisicamente ao objeto que referencia. Este símbolo-índice é também a forma gramatical que faz a passagem da significação para a mostra. Ou seja, para a indicação. E, neste ato, não indica o específico (embora o intente e pretenda), mas indica este universal da partícula (aqui, agora, lá). E, dessa forma, indica, antes, não o ser, mas o próprio ter-lugar da linguagem.

Este ponto de vista poderia ser questionado, uma vez considerado que ele aponta ambos: o universal e o particular. Todavia, este apenas através dos olhos que veem a referência no tempo, enquanto o primeiro é sempre apontado na língua por ela própria, construída de repetiçóes e estereótipos. O que é dizer que a palavra sempre faz referência à própria palavra.

Dando continuidade, ainda é neste ter-lugar da linguagem que o ser se revelaria nos entes. Ou desvelaria de si os seus entes. Mas no advérbio, bem como no pronome, a linguagem indica o universal, e é aí que nos debruçamos sobre a "solução" de Hegel para o problema da apreensão. Hegel parece "resolver" a incapacidade de significar o específico (Diese nehmen, apreender-o-Isto)

7 HEIDEGGER, Martin. Carta Sobre o Humanismo. São Paulo: Editora Centauro, 2005. p. 1.

8 NÖTH, Winfried. Panorama da Semiótica: de Platão a Peirce. São Paulo: Annablume, 2009. p. 59-92.

9 "Mas se quiser vir em socorro da linguagem, que possui a natureza divina de inverter imediatamente o querer-dizer, de transformá-lo em alguma outra coisa e de não o deixar vir à palavra, indicando agora este pedaço de papel, então eu experimento aquela que é a verdade da experiência sensível: eu o indico como um Aqui, que é um Aqui de outros Aqui ou, em si mesmo, um simples agrupamento de muitos Aqui, vale dizer, um universal; eu o tomo como é na verdade e, ao invés de conhecer um imediato, eu percebo (nehme ich wahr, tomo verdadeiro).”. HEGEL, Georg. Fenomenologia do Espirito. p. 92 apud AGAMBEN, Giorgio. A Linguagem e a Morte: um seminário sobre o lugar da negatividade. Belo Horizonte: Ed. UFMG, 2006. p. 27-28. 
da experiência sensível (o não poder ir além dos nomes), considerando a referência da língua aos universais. A linguagem (mediação) refere do mediato (já que o imediato ela não apreende), o universal, sendo este universal a verdade da experiência sensível.

Isto que só pode ocorrer na linguagem, porque o Isto não é. O pronome é um Não-Isto. E o universal é verdadeiro, para Hegel, na medida em que não é nem Isto nem Aquilo, mas um Não-Isto, indiferente, também, todavia, sendo um isto como um aquilo. O Agora, que é noite,

é conservado, ou seja, é tratado como aquilo pelo qual se deu, como um ente (Seindes); ele se mostra, porém antes como um não-ente (Nichtseiendes). O Agora se mantém, de fato, mas como algo que não é noite. Do mesmo modo se mantém contra o dia, que agora é, como algo que nem mesmo é dia, isto é, como um negativo em geral. Este Agora que se mantém não é, portanto, um imediato, mas um mediato; pois ele é determinado como algo que permanece e se conserva precisamente através do fato de que um outro, isto é, o dia e a noite, não é. ${ }^{10}$

Se o Agora, para Hegel, enquanto universal (advérbio) representa o verdadeiro da certeza sensível é devido à sua expressão. É assim que ele resolve o indizível da certeza sensível na linguagem: o universal é na medida em que o outro (a que ele se refere) não é. Agora é porque dia e noite não são, e tampouco são seu ser, embora Agora também seja dia e noite. Para Hegel, tentar dizer a certeza sensível significa experimentar a impossibilidade de dizer o que queremos-dizer (posto que a natureza divina da linguagem é inverter o querer-dizer ${ }^{9}$ ). Mas não como em Elêusis ${ }^{11}$ (a partir da incapacidade da linguagem de proferir o dizível devido à pobreza de palavras ou aos "ressequidos signos"),

10 AGAMBEN, Giorgio. A Linguagem e a Morte: um seminário sobre o lugar da negatividade. Belo Horizonte: Ed. UFMG, 2006. p. 24.

11 "O mistério eleusino da Fenomenologia é, portanto, o mesmo mistério do poema Elêusis: mas, agora, a linguagem capturou em si o poder de silêncio, e o que surgia como indizível "profundeza" pode ser conservado - enquanto negativo - no próprio coração da palavra.". AGAMBEN, Giorgio. A Linguagem e a Morte: um seminário sobre o lugar da negatividade. Belo Horizonte: Ed. UFMG, 2006. p. 28. 
mas porque o próprio universal seria esta verdade da certeza sensível, verdade que a linguagem perfeitamente diz.

A linguagem (carregadora dos universais, sem dúvida), portanto, através dos pronomes (estereótipos da certeza sensível), diria a verdade desta certeza sensível através de seus signos que não significam, mas indicam o ato de indicar. No limite da essência primeira não se diz mais nada, mas indica-se somente. ${ }^{12}$

A linguagem, então, diz da certeza sensível, paradoxalmente, sem proferir o dizível, mas o universal. E, ao invés de ser falha neste seu não dizer, pelo qual apreende o universal no universal, tampouco é tida como prisão às configuraçóes do pensamento ou equívoca, mas passa a livrar o homem do querer-dizer. A própria linguagem, ao dizer a verdade sensível dos universais, de si para si, livra o homem de seu querer-dizer, permitindo que seu ser se abra na linguagem, constantemente. Eis o fundo de negatividade da linguagem amparando o fundo de negatividade do ser. E, poderíamos acrescentar, aqui, ela se livra, também, de seu próprio querer dizer. Mas isto seria considerá-la análoga ao ser do homem, aquele que busca constantemente uma voz. Entretanto, a negatividade do homem é distinta da autorreferência de que é capaz a sua linguagem. Para Agamben, o homem é o único animal que não tem a própria voz, que faça referência direta a ele, como o zurro indicia o asno, e o rechino, a cigarra. A voz do homem seria distinta da $v o z$ animal, pois não o referenciaria, permitindo-lhe abrir-se em sua busca, contra a morte. Enquanto isso, os presos à voz, estariam presos à morte. Mas, no caso da linguagem, ela poderia também estar em busca de sua voz? Antes é preciso destrinchar a transcendência, através dos shifters.

\section{SHIFTERS}

O Agora de Hegel (o Não-isto, o ter-sido), ou, antes, o Diese nehmen (Apreender-o-Isto), se identifica com o ser-no-mundo de Heidegger

12 AGAMBEN, Giorgio. A Linguagem e a Morte: um seminário sobre o lugar da negatividade. Belo Horizonte: Ed. UFMG, 2006. p. 32. 
(o Dasein, ser-o-aî), a partir da existência indicativa, fundo de negatividade que constitui a ambos.

Para os gramáticos gregos, o pronome se aproxima da esfera dos transcendentia. Enquanto estes, todavia, denotam o objeto como objeto de sua universalidade, o pronome - diz-se - indica, por sua vez, uma essência indeterminada, um puro-ser, embora determinável através dos particulares atos de efetuação. ${ }^{13}$

Os shifters ${ }^{14}$, a dixis, a indicação - na qual desde a antiguidade foi individuado o caráter peculiar dos pronomes - não mostra simplesmente um objeto inominado, mas, principalmente, a própria instância do discurso, o seu ter-lugar. Por ser, enfim, como estamos considerando aqui, o fundamento negativo de si própria e do ser que nela se abre - o homem - a linguagem poderia ser considerada ser, uma vez que aquilo que já se mostra em cada ato de fala, sem ser nominado, é ser.

Agamben nos diz que o significado da palavra "ser", busca eterna e eterna perda que cria a história da metafísica, é a do próprio ter-lugar da linguagem. De modo que a metafísica seria a experiência da linguagem que colhe o abrir-se desta dimensão em cada ato de fala. Concluindo-se que

somente porque a linguagem permite, através dos shifters, fazer referência à própria instância, algo como o ser e o mundo se

13 AGAMBEN, Giorgio. A Linguagem e a Morte: um seminário sobre o lugar da negatividade. Belo Horizonte: Ed. UFMG, 2006. p. 38.

${ }^{14}$ Jakobson descreve os shifters como termos cujo significado náo é determinado sem se referir à mensagem sendo comunicada por um emissor a um receptor, dos quais a particularidade consiste na ausência de significado constante e geral, como os pronomes pessoais, ou "aqui" e "agora". Sendo partes de convenção, são símbolos (têm sentido a partir do código), sendo parte da enunciação, são índices (referem a partir da materialidade à qual estão unidos). JAKOBSON, Roman. Shifters and Verbal Categories. In: On Language. Cambridge, MA: Harvard UP, 1990. "Os shifters são distintos de todos os outros constituintes do código linguístico pela sua referência compulsória à mensagem e seu contexto. Sáo uma categoria complexa em que o código (langue) e a mensagem (parole) se sobrepóem, e na qual o significado não pode ser estabelecido sem uma referência ao contexto.". AGAMBEN, Giorgio. A Linguagem e a Morte: um seminário sobre o lugar da negatividade. Belo Horizonte: Ed. UFMG, 2006. p. 152. 
abrem ao pensamento. A transcendência do ser e do mundo - que a lógica medieval colhia no significado dos transcendentia e que Heidegger identifica como estrutura fundamental do ser-no-mundo - é a transcendência do evento de linguagem relativamente àquilo que, neste evento, é dito e significado; e os shifters, que indicam, em todo ato de fala, a sua pura instância, constituem (como Kant havia perfeitamente captado ao atribuir ao eu o estatuto da transcendentalidade) a estrutura lingüística originária da transcendência. ${ }^{15}$

Assim sendo, a dimensão ontológica (ser, mundo) corresponderiam ao puro evento originário do ter-lugar da linguagem, e a dimensão ôntica (os entes, as coisas) àquilo que, nesta abertura, é dito e significado. De modo que a transcendência do ser em relação aos entes, do mundo em relaçáo à coisa, seria a transcendência primeira do evento da linguagem em relação ao que é dito na fala.

Através dos shifters (as pequenas palavras isto, aqui, eu, agora), acredita-se, na Fenomenologia do Espirito ${ }^{16}$, que a certeza sensível poderia captar imediatamente a própria Meinung (ponto de vista), obscura, mostrando-a na sua negatividade. De qualquer modo, presos à transcendência, os shifters indicam sempre o lugar da linguagem, esta que, em seu ter-lugar, identifica-se com a noção de ser. Pois, embora falhe em fazer referência ao mundo, faz referência a si própria, sendo o exemplo de transcendência, onde o ser transcende o ente, o dito transcende o significado, e, porque ela consegue o feito de transcender-se, o mundo transcenda à coisa. Permite aos objetos particulares transcenderem ao referir-se a eles com um universal, religando-os a uma suposta universalidade do ser.

Deparamo-nos, aqui, adverte Agamben, com a séria crença nos universais, pensamento que pode se tornar facilmente logocêntrico. Se a linguagem, através dos shifters, diria a verdade da certeza sensível, através dos seus signos que trariam à tona o ser através do ato de indicar, daí tem-se a consciência de

15 AGAMBEN, Giorgio. A Linguagem e a Morte: um seminário sobre o lugar da negatividade. Belo Horizonte: Ed. UFMG, 2006. p. 43.

${ }^{16}$ HEGEL, Georg. Fenomenologia do Espirito. apud AGAMBEN, Giorgio. A Linguagem e a Morte: um seminário sobre o lugar da negatividade. Belo Horizonte: Ed. UFMG, 2006. 
que a linguagem é constituída de uma negatividade, um vazio, um não-ser. Mas, ao mesmo tempo, que, através deste não-ser, ela poderia carregar o ser, colhendo-o de sua negatividade. Nesta "soluçâo" de Hegel para o problema da apreensão, pode-se facilmente cair no dar um status que as palavras tiveram no Ocidente enquanto lugar da verdade, do conhecimento, da razão, da razoável e certa interpretação (logocentrismo). Status decaído ao longo da história até o "pós-estruturalismo" e a "pós-modernidade". A esfera de transcendência estaria, necessariamente, relacionada a um "vazio do significante", ou à própria arbitrariedade do signo. Neste caso, associados ao "ser".

Roland Barthes, em O Império dos Signos ${ }^{17}$ (publicação de sua fase pós-estruturalista), propóe um esboço do Japão, no qual este lugar, em oposição ao Ocidente, teria toda técnica (incluindo a linguagem, enquanto técnica, permeada por um modo de se relacionar com signos e inteligências intrínsecas a ela) evitando o centro e $o$ significado transcendental (assim, do centro de Tóquio ao Palácio do Imperador, ver-se-iam presenças silenciosas, evitando as entidades centrais). Comparado, assim, ao modo ocidental (logocêntrico-racionalista), como local de um esvaziamento do significante (dinâmica do significante que evita/afasta/esquece o significado), o Japão nos revelaria outra tentativa de transcendência da linguagem a partir de sua negatividade constituinte. Na forma poética do haikai, a busca pela justa medida, pela "adequação entre significado e significante" 18 , eliminação de ruídos e extensôes de um ou de outro, ou seja, o impedimento da cópula em segundos sentidos, visaria a findar o falatório incessante, visto como impedimento ao Zen. O fim da linguagem provocaria o arrombamento do sentido, o satori ("iluminaçâo", termo ainda demasiado Ocidental). O satori sendo estado de transcendência em que a linguagem apenas se contempla, indica-se (fundo de negatividade), mas não se diz, não se estende, existindo calma do mesmo modo que o haikai indica o Isto. Esta forma poética pretende se mimetizar ao Isto, sem o descrever, adjetivar ou explicar (racionalizar, interpretar, dotar de sentido superior, ao modo ocidental). O haikai seria o "Isto", nas palavras de Barthes, semelhante à fotografia tirada sem a película, ou ao gesto da criança que aponta com um dedo o nada, no qual se vê o próprio gesto de apontar. O apontar é o sentido.

17 BARTHES, Roland. O Império dos signos. 1. ed. São Paulo: Martins Fontes, 2007.

18 BARTHES, Roland. O Império dos signos. 1. ed. São Paulo: Martins Fontes, 2007. p. 97-100. 
Mas não se pode igualar qualquer esvaziamento dos signos à negatividade fundamental da linguagem (o primeiro, certo peso na dinâmica entre significado e significante e o segundo, característica ontológica do ser e da linguagem). Esta consideração visa, na olhadela ao Zen, tracejar o problema que é, para o pensamento logocêntrico ocidental, a transcendência da linguagem em sua negatividade, uma vez considerada toda a busca por significado (inclusive a busca metafísica pelo ser), toda a crença na verdade, toda a racionalidade atribuída à palavra, à linearidade, à acumulação, à perenidade, associadas à escrita. Frente a esta negatividade, o modo ocidental insistiu sempre em seu querer dizer. Avolumando ora os significados em detrimento dos significantes, ora o inverso, todavia, apenas conseguindo fazer entrever, em sua produção escrita e oral, ao longo da história, nestes rasgos de distância em que o espaço da linguagem aparece, o ser da linguagem em metalinguagem, em autorreferência. A representação da literatura ocidental não disfarçou a inadequação, a impossibilidade da unidade-signo, como o modo japonês na forma poética do haikai, dissimuladora da tensão entre significado e significante, silenciadora da discrepância entre os universais e as coisas, entre o ser e os entes, entre o dizer e sua referência. Sendo assim, a linguagem contemporânea é fruto desta problemática. Cotidianamente, dá-se em sua negatividade natural somada a um mundo globalizado e capitalista, de superprodução de discursos, implosão de qualquer "real" ou fim ou referência.

\section{A VOZ}

Antes de tratar da transcendência da linguagem na contemporaneidade, há um elemento a ser considerado: a Voz. O Dasein (ser-o-aì), de Heidegger, introduz o homem a uma negatividade que tem seu fundamento no $D a$, o $A i$, que, por sua vez, remete ao puro ter-lugar da linguagem, assim como o Isto. Distintos daquilo que, neste ter-lugar, seria formulado em proposiçóes linguísticas. Todavia, o aí, o lá, o agora, o eu da língua não são passíveis de serem contidos e só existem mediante o ser e uma voz, ou seja, uma enunciação no tempo (o conceito linguístico de enunciação pareia-se com o conceito da história da metafísica de "ser"). Sem a voz, não há enunciação. Assim também é com o apreender-o-Isto, de Hegel, pois o shifter remete, quando tenta ser dito (ou pensado), não ao objeto, mas à própria linguagem. Esta que, nesta capacidade de se autorremeter, tem também seu próprio fundamento de negatividade, que é seu próprio ter-lugar. 
Podemos questionar, enfim, o que manteria esta harmonia, em que o ser do homem abre-se na linguagem, evitando assim a morte (a linguagem contra a morte), e permitindo a ambos serem, uma vez que este abrir-se ocorre sob um duplo fundo de negatividade - o do ser e o da linguagem.

Como a transcendência da linguagem permitiria ao homem (o falante e $o$ mortal) ser? Finalmente, como isto se explica: que o animal, aquele que teria a sua própria voz $^{19}$, estaria por esta preso à sua própria negatividade (à morte), enquanto o homem, sem voz, a não ser uma voz negativa, na busca dessa dentro da linguagem, manter-se-ia Dasein (abrindo-se)?

A voz enquanto mero som (voz animal) é índice daquele que a emite, mas não remete à instância do discurso, não abre a esfera da enunciação:

A voz, a $\varphi \omega v \eta$ animal, é, sim pressuposta pelos shifters, mas como aquilo que deve ser necessariamente suprimido para que o discurso significante tenha lugar. $\mathrm{O}$ ter-lugar da linguagem entre o suprimir-se da voz e o evento de significar é a outra Voz, cuja dimensão onto-lógica vimos emergir no pensamento medieval e que, na tradição metafísica, constitui a articulação originária (...) da linguagem humana. ${ }^{20}$

Então, surge esta outra Voz, atrelada à tradição metafísica. Tratar-se-ia de uma $\mathrm{Voz}$ anterior, que se revelaria enquanto pronome supremo (que remete a si mesmo). A Voz se revelaria na voz. Isto porque se não houvesse uma Voz

19 "Pensar, na linguagem, nós o podemos apenas porque a linguagem é e não é a nossa voz. Existe uma pendência, uma questão não resolvida na linguagem: se ela é ou não a nossa voz, como o zurro é a voz do asno e o rechino é a voz das cigarras. Por isso, não podemos, falando, deixar de pensar, de manter em suspenso as palavras. O pensamento é a pendência da voz na linguagem. (...) $\mathrm{O}$ animal, em fuga, cujo rumor parece-nos ouvir sumindo nas palavras é - disseram-nos - a nossa voz. (...) Mas a voz, a voz humana não existe. Não há uma voz nossa de que possamos seguir o rastro na linguagem, que possamos colher - a fim de recordá-la - no ponto em que se dissipa nos nomes, em que se escreve nas letras. Nós falamos com a voz que não temos, que jamais foi escrita (...). E a linguagem é sempre "letra morta”. AGAMBEN, Giorgio. A Linguagem e a Morte: um seminário sobre o lugar da negatividade. Belo Horizonte: Ed. UFMG, 2006. p. 38.

20 AGAMBEN, Giorgio. A Linguagem e a Morte: um seminário sobre o lugar da negatividade. Belo Horizonte: Ed. UFMG, 2006. p. 56. 
maior, a linguagem humana não teria este poder de ser. Entretanto, a Voz não está completamente aí, posto que a voz do homem não existe, mas a Voz (entre o suprimir-se da voz animal e o evento de significar) permite que ele continue em seu movimento, sem que caia em um plano de completa negatividade. Ela - Voz - é, entáo, o elemento que evitaria a pura negatividade, em que cairiam a linguagem e o homem. Definindo-se pela dupla negatividade: a Voz é considerada como voz suprimida, como ter-sido da $\varphi \omega v \eta$ (voz) natural, e este suprimir-se é a articulação originária ( $\alpha \hat{\rho} \theta \rho o v)$ em que se efetua

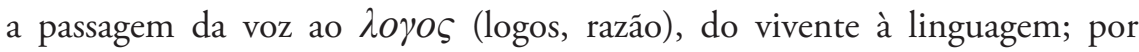
outro lado, a Voz não pode ser dita pelo discurso do qual mostra o ter-lugar originário. De forma que a articulação originária da linguagem tem lugar em uma dupla negatividade, diferentemente de como o zurro é a voz do asno e o rechino é a voz da cigarra, referências imediatas, e ela permite ao homem, não sendo sua própria voz, ser-o-ai e apreender-o-Isto na experiência do ter-lugar da linguagem e da abertura do ser.

Por outro lado, porém, (como mostram a dialética heideggeriana de Stimmung e Stimme e a figura hegeliana da Voz da morte) se o homem náo tivesse radicalmente voz (nem mesmo uma Voz negativa), todo shifter, assim como toda possibilidade de indicar o evento de linguagem, se extinguiria ${ }^{21}$.

Portanto, há de haver uma Voz silenciosa e indizível, além da voz e da linguagem, shifter supremo que permite ao pensamento ter experiência do ter-lugar da linguagem (e ser transcendendo o ente). Esta Voz não poderia ser dita, mas existiria como forma de indicar o evento da linguagem. Ela seria o lugar originário da negatividade e o mitologema original da metafísica. Sendo a negatividade, portanto, inseparável da metafísica. Neste ponto, Agamben aponta o limite da crítica à metafísica de que são exemplos a filosofia da diferença, o pensamento negativo e a gramatologia (combatentes do logocentrismo), enquanto acreditam ultrapassar o horizonte da metafísica radicalizando o problema da negatividade e da não-fundamentação. Sendo que consideram a superação da metafísica a pura e simples repetição de seu problema fundamental.

21 AGAMBEN, Giorgio. A Linguagem e a Morte: um seminário sobre o lugar da negatividade. Belo Horizonte: Ed. UFMG, 2006. p. 116. 
À pergunta: << o que existe na Voz? >>, a filosofia responde: nada existe na voz, a voz é o lugar do negativo, é Voz, ou seja, pura temporalidade. Mas esta negatividade é, porém, grámma - pura auto-afecção negativa, traço de si mesmo, aquilo que é na voz, quantum de voz significante, fundamento que sustém o inteiro círculo da significação - (...) que articula voz e linguagem e abre, assim, o ser e o sentido. ${ }^{22}$

Assim, Agamben critica a crítica de Derrida à tradição metafísica, reconhecendo que este filósofo identificou - ao desenvolver com rigor o conceito levinasiano de traço e o heideggerriano de diferença - o estatuto original do grámma e do significante em nossa cultura, todavia, tendo acreditado abrir, assim, o caminho para a superação da metafísica, quando, a seu ver, apenas teria trazido à tona seu problema fundamental:

A metafísica não é, com efeito, simplesmente o primado da voz sobre o grámma. Se a metafísica é aquele pensamento que coloca na origem a voz, é também verdade que esta voz é, desde o início, pensada como suprimida, como Voz. Identificar o horizonte da metafísica simplesmente na supremacia da $\varphi \omega v \eta$ e crer, então, poder ultrapassar este horizonte por meio do $\gamma \rho \alpha ́ \mu \mu \alpha$ significa pensar a metafísica sem a negatividade que lhe é coessencial. A metafísica já é sempre gramatologia, e esta é fundamentologia, no sentido de que ao grámma (à Voz) compete à função de fundamento ontológico negativo ${ }^{23}$. ( $\varphi \omega v \eta-v o z ; \gamma \rho \alpha ́ \mu \mu \alpha-$ gramma)

Seria necessário, com maior tempo e cuidado, analisar esta colocação de Agamben acerca de Derrida, no que tange à Voz. É sabida, a partir da obra de

22 AGAMBEN, Giorgio. A Linguagem e a Morte: um seminário sobre o lugar da negatividade. Belo Horizonte: Ed. UFMG, 2006. p. 60.

23 AGAMBEN, Giorgio. A Linguagem e a Morte: um seminário sobre o lugar da negatividade. Belo Horizonte: Ed. UFMG, 2006. p. 61. 
Derrida, que a crítica ao logocentrismo visaria não apenas conceitualmente "libertar" o Ocidente da metafísica, mas de certos modos de pensar. Neste sentido, se a linguagem seria inevitavelmente fascista, como nos aponta Barthes, não por permitir dizer algo e não outro, mas por obrigar a dizer ${ }^{24}$, seria preciso observar formas de torcê-la em seu interior. Não buscar atrás dela um fundo. Mas criar dela possibilidades.

\section{ABRIR-SE DO SER NA LINGUAGEM NA CONTEMPORANEIDADE}

A negatividade da linguagem pode ser observada de uma forma particular no contemporâneo. Além da negatividade essencial, em que o vazio do signo o impede de apreender o Isto, haveria o esvaziamento do signo ao longo da história. Isto corresponde ao fim da busca pela Voz, enquanto shifter supremo, (que faz referência a si e sustenta a negatividade da linguagem). Esta que foi paralela à busca pela palavra interior ao pensamento e pela palavra anterior à exteriorização. Análoga ao Verbum divino, que sustentaria a negatividade de toda a existência, desde o início estando com Deus e sendo Deus. O Verbo ${ }^{25}$ é shifter supremo: "Aquele que é o que é"26. Ao se fazer carne é duplo sentido (Cristo encarnado e Palavra encarnada) e gera no pensamento da linguagem a busca por sentido maior, pela Palavra que se revela na palavra, o Cristo encarnado a cada nova pregação, a cada nova morte. Seria possível considerar, de Nietzsche ("precursor" do pós-estruturalismo, que desfará as últimas barreiras da "crença no signo"), a morte de Deus enquanto morte da linguagem (esta que não se separa do homem, que também "morre", uma vez "morto Deus"). Sua morte seria a perda da sustentação, do calção do shifter supremo, enquanto forma de idealismo que sustentaria a palavra enquanto lugar da Razão, da

24 BARTHES, Roland. Aula: Aula inaugural da cadeira de semiologia literária no Colégio de França, pronunciada dia 7 de janeiro de 1977. Tradução Leyla Perrone-Moisés. 1. ed. São Paulo: Cultrix, 2007.

25 “(...) os homens, os viventes, são "incessantemente remetidos à morte através de Cristo" (...), ou seja, através do Verbo, e é esta fé que os move à palavra.”. AGAMBEN, Giorgio. A Linguagem e a Morte: um seminário sobre o lugar da negatividade. Belo Horizonte: Ed. UFMG, 2006. p. 10.

26 “Disse Deus a Moisés: EU SOU O QUE SOU.”. Êxodo 3:14. A Bíblia Sagrada. Edição Almeida Revista e Atualizada. Sociedade Bíblica do Brasil, 1959. 
Verdade, do Sentido. Assim, a linguagem cairia, talvez, no mesmo processo do homem de niilismo até ser afirmada de novas formas. Talvez a aproximação seja ousada, mas, se pensarmos no niilismo em que recai o homem à mercê de seus próprios valores superiores, não mais divinos, após a morte de Deus, podemos pensar na estrutura niilista da sociedade contemporânea através de seus enunciados.

O Dasein, pró-jeto projetado, abre-se no ser da linguagem na contemporaneidade. Esta o lança em um horizonte de pura velocidade, onde todos os sólidos nos quais ele creu, inclusive a identidade, estão desfeitos. Toda a perspectiva de fim se acaba na pós-modernidade, momento em que a modernidade aceita sua aceleração. A categoria texto, que apostava no tempo enquanto forma de existência, é desfeita. Os modelos teóricos, baseados na razão, são substituídos por modelos de simulação. Restam as práticas de enunciação virtuais, em que a linguagem lança-se ao devir do tempo real.

Uma rede de microblogging, como o Twitter, leva-nos a uma constelação de representações do cotidiano. Os status postados a partir de onde os indivíduos estejam, no limite de 140 caracteres, dizem "o que eles estão fazendo". No exercício de criar esta microimagem do presente, congelando-o pela escrita, que é, todavia, virtual e lançada à rede, o indivíduo confere mínimo sentido à fragmentação existencial, recusa o vazio do momento pela força de dizê-lo, confessa-o, libera-o de sua ausência de sentido. Dado a um banco de informaçôes, há chances de que ele seja significado por alguém, ou útil por algum momento, pragmaticamente. Mas o que se esperaria é que ele afirmasse seu momento, através da linguagem, e não caísse no niilismo da confissão e do sentido mínimo, como ocorre, por vezes. Ainda assim, afirmando ou negando, o indivíduo da representação virtual exercita o devir, pois a linguagem não represa o presente como no polo da escrita. O vir-a-ser do Dasein (pura possibilidade, instância de finitude, ser-para-a-morte) é vislumbrado nesta "palavra-devir”, em fluxo e profusão de novos discursos incessantemente. Palavra para consumo, descartável, nômade e turista. A experiência de dizer na rede é negativa. O Twitter opera em pura possibilidade e simulação, é um espaço em que o real é transformado em hiper-real e a palavra, além de ser desde sempre signo vazio, é traduzida em bits e, como todas as demais formas sensoriais - sons, imagens -, tem sua especificidade apagada pelo sistema binário de tradução em zeros e uns. O emblemático nome Twitter resume o status da palavra no 
contemporâneo: "estouro curto de informaçóes inconsequente", "ruídos de pássaros" (idênticos, sem sentido em si, cujo sentido é aplicado por outras aves) ${ }^{27}$. A palavra virtual é desfeita do idealismo da encarnação. Nela, o dizer "encarna-se" em pura negatividade, mas é apenas simulação do ser-para-a-morte.

Neste contexto, colocamos a pergunta de Agamben: o que acontece com a palavra quando some o grámma, ou a Voz?

A filosofia é este diálogo do homem - o falante e o mortal com sua Voz, este estrênuo reencontrar a Voz - e, com ela, uma memória - diante da morte, assegurando assim à linguagem o seu lugar. A Voz é o mudo companheiro ético que corre em socorro da linguagem no ponto em que esta revela a sua náo-fundamentação. Calando, com o seu <<sopro>>, a Voz assume esta ausência de fundamento e lhe dá lugar. (...) No solilóquio de Édipo, todavia, a Voz é, no fim, apenas uma <<maldição >> impotente e uma ilusão e, como tal, deve também ela perecer. (...) "Não sentir - escreve Nietzsche - após, semelhante apelo do profundo da alma, nenhuma voz em resposta é uma experiência terrível, que pode destruir o homem mais duro: em mim cortou todos os laços com os homens vivos.". (...) Com a definitiva morte da Voz, também a filosofia - solilóquio de Édipo - deve ter fim. O pensamento que pensa após o fim da filosofia não pode continuar a ser pensamento $\mathrm{da} \mathrm{Voz}$, do ter-lugar da linguagem na Voz. Este pensamento não pode ser, porém, nem mesmo pensamento da morte da Voz. Somente se a voz humana não morreu simplesmente, mas não existiu mais, somente se a linguagem não remete mais a Voz alguma (e, portanto, nem mesmo a uma $\gamma \rho \alpha ́ x \mu \alpha$, ou seja, a uma voz suprimida) se torna possível para o homem uma experiência da palavra que não seja marcada pela negatividade e pela morte. ${ }^{28}$

27 TWITTER creator Jack Dorsey illuminates the site's founding document. Los Angeles Times Business, 18 fev. 2009. Disponível em: <http://latimesblogs.latimes.com/technology/2009/02/ twitter-creator.html>. Acesso em: 10 jan. 2012.

28 AGAMBEN, Giorgio. A Linguagem e a Morte: um seminário sobre o lugar da negatividade. Belo Horizonte: Ed. UFMG, 2006. p. 126. 
A experiência da supressão da Voz é experimentada com niilismo. Sem Voz, o ser e a linguagem entram na simulação, sustentando-se no vazio inescapável, do qual se ressentem. Segundo Jean Baudrillard ${ }^{29}$, não vivemos o real, já cindido pelos signos dos valores, formando-se numa espiral desde o fim das trocas simbólicas primitivas, formas de anular a morte. De forma que a hiper-realidade em que vivemos é marcada pela morte fractal, pela sobrevivência. Ao invés de deixar de existir, a voz caminha a saturação, usada a bel prazer (sem rituais, limites religiosos ou poéticos), em superprodução, à semelhança da mercadoria, como recurso renovável e ilimitado.

Talvez o tempo das coisas absolutamente dizíveis, cujo extremo furor niilista nos é dado hoje experimentar; o tempo em que todas as figuras do Indizível e todas as máscaras da onto-teológica foram liquidadas, ou seja, solvidas e pagas em palavras que mostram simplesmente o nada sobre o qual se fundam; o tempo em que toda a experiência humana da linguagem foi reconduzida à última realidade negativa de um querer-dizer nada; talvez este tempo seja também aquele em que se possa tornar novamente visível a morada in-fantil (in-fantil, ou seja, sem vontade e sem Voz, e todavia, ética, habitual) do homem na linguagem. ${ }^{30}$

A troca só poderia ser desfeita pelo poético que torce a linguagem desde seu interior, nas palavras e fonemas. Para Nietzsche, a única forma de retirar o homem do niilismo é a arte, a qual, mesmo ilusão, gera um olhar criador e afirmativo sobre as formas. Para chegar à infância, ter-se-ia de superar a morte da palavra e o discurso desta morte. Sem a Voz, o homem pode libertar-se de abrir-se através da negatividade e provar uma nova experiência da palavra, não mais marcada pela negatividade ou pela morte. Resta perguntar: como?

29 BAUDRILLARD, J. Simulacros e Simulação. Lisboa: Relógio d'Água, 1991.

30 AGAMBEN, Giorgio. A Linguagem e a Morte: um seminário sobre o lugar da negatividade. Belo Horizonte: Ed. UFMG, 2006. p. 125-126. 


\section{O "ETERNO RETORNO" DA LINGUAGEM - CONSIDERAÇÃO FINAL SOBRE O SER DA LINGUAGEM}

"Escrever para não morrer, como dizia Blanchot, ou talvez mesmo falar para não morrer (... $)^{m 31}$, permite, no recuo contra a morte, à linguagem delongar-se ao infinito. Seja um infinito afirmativo ou niilista.

Dispondo os infortúnios, (pré)textos dados dos deuses aos homens, a fim de serem narrados, no acúmulo das palavras, no longínquo ocaso, "onde elas enfim cessarão, elas que não querem se calar" 23 , a linguagem mesmo esconde seu fim, como faz o homem ao delongar suas venturas na representação. $\mathrm{Na}$ relação ser do homem - ser da linguagem ambos se abrem, atravessando-se. Mas não seria cabível imaginar a linguagem como um ser que usaria o homem como pretexto, um ser análogo ao homem.

O mistério eleusino (que integrou o pensamento do jovem Hegel) consistiria em experimentar no silêncio a negatividade que é inerente a todo o querer-dizer, na qual o iniciado aprenderia a não dizer o que quer-dizer, sem, todavia, calar: "Assim como o animal traz consigo a verdade das coisas sensíveis simplesmente devorando-as, reconhecendo-as então como nada, a linguagem conserva o indizível dizendo-o, ou seja, colhendo-o da sua negatividade." 32 Aqui a negatividade da linguagem é próxima à paralisia do animal, que diria devorando, "passivamente", inerte, preso à morte. Nesta perspectiva, seria análoga a uma negatividade selvagem. Quanto ao homem, em Elêusis, no momento em que se percebesse a impossibilidade de se dizer, cairia no silêncio de sua impossibilidade de significar o específico, o verdadeiro, o imenso, devido aos ressequidos signos. O que, como vimos, Hegel modifica depois, com a sua solução.

Como terceira hipótese, comparamo-la com a potência determinada, que é o mundo, para Nietzsche. O que nos parece mais cabível. De forma que não se faz possível pensar em uma morte da linguagem. Assim como o mundo de Nietzsche não tem começo nem fim. Este ocaso onde as palavras cessariam

31 FOUCAULT, Michel. Linguagem ao Infinito. In Coleçâo Ditos e Escritos - Michel Foucault: Estática: Literatura e Pintura, Música e Cinema. Rio de Janeiro: Editora Forense Universitária, 2006. p. 47.

32 AGAMBEN, Giorgio. A Linguagem e a Morte: um seminário sobre o lugar da negatividade. Belo Horizonte: Ed. UFMG, 2006. p. 28. 
(objetivo do Zen), ao menos, no Ocidente, não há. Nem a implosão de sentido impede o discurso de se reproduzir. ${ }^{33}$ Esmaece, renasce, mas não morre. A abertura contra a morte não pode morrer. À semelhança do mundo, a língua retornaria sempre, em número de combinaçôes calculável e infinitas repetiçôes ("das diferenças" ${ }^{4}$ ), a jogar in infinitum contra si mesma, sem diminuiçôes, acréscimos, rendimentos ou desperdícios,

com uma vazante e enchente de suas configuraçóes, partindo das mais simples às mais múltiplas, do mais quieto, mais rígido, mais frio, ao mais ardente, mais selvagem, mais contraditório consigo mesmo, e depois outra vez voltando da plenitude ao simples, do jogo de contradiçóes de volta ao prazer da consonância, afirmando ainda a si próprio, nessa igualdade de suas trilhas e anos, abençoando a si próprio como Aquilo que eternamente tem de retornar, como um vir-a-ser que náo conhece nenhuma saciedade. ${ }^{35}$.

Assim, a linguagem conserva-se em seu ser a criar-a-si e destruir-a-si. Seu fim lançado ao dos infortúnios que narra, para si mesma, no "relato do relato e essa articulação que poderia não terminar nunca."36

33 A simulação substitui a realidade, a ideologia, o capital, correspondendo à $3^{\text {a }}$ ordem do valor. Os estágios do valor se sucedem: lei natural (quando o valor faz referência a um uso natural no mundo), lei mercantil (quando este faz referência a um equivalente geral, à mercadoria), lei estrutural (quando o valor faz referência a um código e a modelos) e lei fractal, viral ou irradiada do valor (atual, em que já não há nenhuma referência, o valor irradiando-se em todos os interstícios, por contiguidade). O problema é que nesta espiral de simulacros baseada nas substituiçóes sígnicas do valor, sem mais retorno ao real, mas indo de um signo de valor ao outro, se oculta a ideia de morte (perdida na simulação para atrás de uma cadeia infinita de significados - a semiose ilimitada do valor). DELEUZE, Gilles. Nietzsche. Lisboa: Ediçôes 70, 1985.

35 NIETZSCHE, Friedrich. Obras Incompletas. 3. ed. São Paulo: Abril Cultural, 1983. p. 397.

36 FOUCAULT, Michel. Linguagem ao Infinito. In: Coleção Ditos e Escritos - Michel Foucault: Estática: Literatura e Pintura, Música e Cinema. Rio de Janeiro: Editora Forense Universitária, 2006. p. 48. 


\title{
THE NEGATIVITY OF LANGUAGE AND THE VOICE IN GIORGIO AGANBEN
}

\author{
ABSTRACT \\ The articles reviews the relationship between language \\ and death, from the book in which G. Agamben treats \\ the fundamental negativity of the being of language and \\ being of man as dialectical motors that enable the very \\ opening of the being in the place of language, suppor- \\ ted by the negativity of his Voice. Added to that, we \\ raise questions about the status of language in contem- \\ porary societies. \\ KEYWORDS: negativity of language; language and \\ death; Giorgio Agamben.
}

Recebido em: 27/07/2012

Aprovado em: 06/02/2013 